\title{
Udomiteljstvo iz perspektive udomitelja Roma u romskim naseljima u Međimurskoj županiji
}

\author{
Mateja Krčar \\ Centar za socijalnu skrb Čakovec \\ Maja Laklija \\ Pravni fakultet Sveučilišta u Zagrebu, Studijski centar socijalnog rada \\ E-mail: maja.laklija@pravo.hr
}

\begin{abstract}
Sažetak
Udomiteljstvo je jedan od oblika skrbi za djecu koji se javlja kao alternativa institucionalnom zbrinjavanju djece, a njegova je prednost upravo u činjenici obiteljskog okruženja. Cilj ovog istraživanja bio je dobiti uvid u iskustva udomitelja pripadnika romske nacionalne manjine ( $N=7$ ) u pružanju udomiteljske skrbi za djecu u romskim naseljima u Međimurskoj županiji. Dobiveni rezultati pokazuju da je romske udomitelje na udomiteljstvo potakla želja za pružanjem primjerene skrbi djeci, postojanje uvjeta za bavljenje udomiteljstvom, kao i iskustvo udomiteljstva u vlastitoj obitelji. Sudionici u ovom istraživanju kao otežavajuće okolnosti u pružanju udomiteljske skrbi navode razne reakcije sumještana na njihovo bavljenje udomiteljstvom, ponašanje bioloških roditelja djece, ponašanja djece te život u romskom naselju zbog specifična načina života Roma. Osnažujuće okolnosti u pružanju udomiteljske skrbi su: socijalna podrška, tzv. emocionalni 'efekti' udomiteljstva na udomitelje kao i život u romskom naselju zbog očuvanja kulture, jezika i pripadnosti. Praktična je implikacija istraživanja produbljivanje razumijevanja ovoga tematskog područja, a rezultati, osim za promišljanje o budućim istraživanjima, pružaju smjernice za praktično djelovanje na razini poboljšanja kvalitete skrbi i brige za romsku djecu u udomiteljskoj skrbi te unapređenju podrške romskim udomiteljima u skladu s njihovom tradicijom i kulturom.
\end{abstract}

Ključne riječi: udomiteljstvo, djeca, socijalna skrb, romske obitelji, romsko naselje

\section{Uvod}

Djeca u romskim obiteljima nerijetko odrastaju u težim uvjetima i nemaju jednake mogućnosti ravnopravna sudjelovanja u društvu. Za neku romsku djecu rast i razvoj u primarnim obiteljima može biti ugrožen jer žive u nepovoljnim okolnostima zbog kojih sustav socijalne skrbi mora djelovati. Konvencija o pravima djeteta (Državni zavod za zaštitu materinstva i mladeži, Zagreb, 2001) navodi da je jedno od prava djeteta pravo na zamjensku pomoć smještanjem u udomiteljsku obitelj, posvojenjem ili boravkom u ustanovi za skrb o djeci. Zamjetno je da, osim što djeca romskog podrijetla imaju manje šanse od ostale djece biti smještena u udomiteljske obitelji, nedostaje i romskih udomiteljskih obitelji, tako da često ta djeca duže ostaju u institucionalnoj skrbi u odnosu na ostalu djecu (Kennedy, Kukk i Mansens, 2010). Također, romska su djeca često neopravdano kategorizirana kao djeca s intelektualnim teškoćama, što dodatno otežava njihovo udomljavanje i posvojenje (Anghel, Herczog i Dima, 2013). S druge strane, uzimajući u obzir važnost da dijete odrasta u svojoj kulturi i gradi svoj kulturološki identitet, javlja se i problem dolaženja do novih potencijalnih romskih udomiteljskih obitelji koje bi to omogućile, najviše zbog neispunjavanja zakonskih 
preduvjeta zainteresiranih romskih obitelji za dobivanje dozvole, na što ukazuje Nacionalna strategija za uključivanje Roma za razdoblje od 2013. do 2020. godine (Vlada RH, 2012). Naime, potencijalne udomiteljske obitelji često ne ispunjavaju dohodovni cenzus, često nemaju završenu potpunu osnovnu školu ili imaju osnovnoškolsko obrazovanje stečeno na pučkom učilištu. Također, prema Nacionalnom programu za uključivanje Roma (Vlada RH, 2012), potencijalni problem u regrutiranju novih romskih udomitelja odražava se i u infrastrukturi romskih naselja, što dovodi u pitanje prikladnost udomitelja iz tih naselja za pružanje udomiteljske skrbi za dijete i gledanje sumještana na udomiteljstvo kao način zarade. Unatoč tomu centri za socijalnu skrb nalaze načine za uvođenje novih romskih obitelji u sustav udomiteljstva. U Nacionalnom programu za uključivanje Roma (Vlada RH, 2012) u području socijalne skrbi navedeno je upravo poticanje razvoja udomiteljske skrbi u romskim obiteljima, posebice za smještaj djece bez odgovarajuće roditeljske skrbi, što bi kontinuirano trebali provoditi centri za socijalnu skrb, nevladine organizacije i Ministarstvo za demografiju, obitelj, mlade i socijalnu politiku.

U Republici Hrvatskoj nedostaju istraživanja u području udomiteljstva na populaciji pripadnika romske nacionalne manjine. S obzirom na navedeno te na Plan deinstitucionalizacije i transformacije domova socijalne skrbi i drugih pravnih osoba koje obavljaju djelatnost socijalne skrbi u Republici Hrvatskoj od 2011. do 2016. (2018.) (Ministarstvo zdravstva i socijalne skrbi, 2010) koji ističe važnost razvoja udomiteljske skrbi, te potrebu za promoviranjem udomiteljstva i pronalaženjem novih udomitelja, uključujući regrutiranje udomitelja pripadnika romske nacionalne manjine, smatrali smo važnim istražiti iskustvo udomitelja pripadnika romske nacionalne manjine te otvoriti i neke teme za daljnja istraživanja.

\section{Udomiteljstvo djece pripadnika romske nacionalne manjine u nekim europskim zemljama}

U Europi je zamjetan zabrinjavajući trend rasta broja djece u sustavu institucionalne skrbi, a naročito ranjivih skupina djece u koje spadaju i romska djeca (Vandekereckhove, 2011, Vijeće Europe, 2012). Pozivajući se na izvješća Europskog centra za prava Roma, McGaughey, Curran, Fay, Nurse i Garland (2012) izražavaju zabrinutost u vezi s pravima i pitanjima koja se odnose na zaštitu romske djece u Europi, ukazujući, među ostalim, na velik broj romske djece zastupljene u sustavu institucionalne skrbi u europskim zemljama. ${ }^{1}$ Daugherty Bailey i Schmidt (2014) navode da je tomu tako jer sustav socijalne skrbi još uvijek daje prednost institucionalnom smještaju, naročito za romsku djecu. Europska mreža pravobranitelja za djecu [ENOC] (Vandekereckhove, 2011) navodi problem nedostatka podataka za uspoređivanje različitih zemalja Europske unije budući da većina zemalja EU-a ne prikuplja i/ili u službenim izvješćima ne objavljuje podatke o nacionalnosti djece (McGaughey i sur., 2012). Nadalje, ne zna se točan broj romske djece koja su korisnici udomiteljstva zbog prava na izbor roditelja i djeteta da navedu svoju nacionalnost. S obzirom na dostupnost izvora, koji se odnosi na ovo tematsko područje, u nastavku su prikazane situacije u zemljama čiji su podatci i istraživanja bili dostupni autorima.

1 Podatci za Bugarsku govore da je od 50 \% do 63 \% djece u domovima za djecu romske nacionalnosti (Vijeće Europe, 2012.; McGaughey i sur., 2012). U Češkoj taj postotak iznosi 33 \% prema McGaughey i suradnicima (2012) dok Vijeće Europe (2012) navodi postotak od $40 \%$ romske djece. U Mađarskoj je $65 \%$ romske djece u domovima za djecu, u Rumunjskoj 31,8 \% dok u nekim regijama taj postotak raste i do 80 \% (Vijeće Europe, 2012.; McGaughey i sur., 2012). Italija ima postotak od 10 \% romske djece u domovima za djecu dok ih je u obiteljskim domovima 45 \% (Vijeće Europe, 2012). Slovačka ima između 70 \% i 95 \% romske djece u dječjim domovima, a jedan je od razloga tomu smještaj djece u domove radi obrazovanja (Vijeće Europe, 2012). 
Smith Rotabi i Hübinette (2017) navode da se u 18. stoljeću u Carevini Austriji 18000 romske djece nalazilo na smještaju u katoličkim udomiteljskim obiteljima u sklopu projekta prisilne asimilacije usmjerenog prema romskom stanovništvu te da su taj primjer slijedile i druge nacije u Europi. lako je danas situacija vezano uz okolnosti izdvajanja i smještaja u udomiteljstvo romske djece drukčija, zamjetne su poteškoće vezane za skrb romske djecu izvan vlastite obitelji. Usprkos međunarodnim kritikama i želji za promjenom, u češkom sustavu socijalne skrbi romska djeca kategorizirana su kao neprikladna za skrb u udomiteljskim obiteljima zbog pristranosti sustava prema institucionalizaciji te je za njih upravo institucionalna skrb bila prioritetan oblik skrbi, iako se naglašava važnost podrške obitelji i alternative takvoj skrbi (Daugherty Bailey i Schmidt, 2014). Da bi se smanjio broj romske djece u domovima, u Mađarskoj se romske obitelji potiče na uključivanje u edukaciju za udomitelje. Međutim, taj proces ide sporo zbog loših uvjeta stanovanja romskih obitelji zbog kojih ne zadovoljavaju uvjete za bavljenje udomiteljstvom, ali i zbog predrasuda većinske populacije prema Romima (Family, Child, Youth Association, 2014). Predrasude se mogu uočiti u negativnim stavovima većinskog stanovništva prema Romima, koje opisuju kao neiskrene, agresivne, loše osobne higijene, bez stečenih radnih navika, nezaposlene, niska obrazovnog statusa te sklone činjenju kaznenih djela (Rosenfield, 2010). U Irskoj je prepoznata neprihvatljivost smještanja romskog djeteta u okruženje koje je kulturološki različito te se ističe potreba za odgovarajućim udomiteljskim obiteljima za romsku djecu (McGaughey i sur., 2012). U Rumunjskoj je prepoznat, među ostalim, problem velikog broja romske djece u institucionalnoj skrbi, gdje su djeca izložena ponižavajućim ponašanjima prema njima, pa i zlostavljanju (D’Arcy i Brodie, 2015). U Rumunjskoj je i jedan od uvjeta za dobivanje udomiteljske licencije sposobnost odgoja djece pripadnika različite nacionalnosti, prije svega romske, što doprinosi kvaliteti pružanja skrbi (Sirius - Centar za psihološko savjetovanje, edukaciju i istraživanje, 2017). U Albaniji je proveden pokusni projekt kojim su se osigurala sredstva i podrška za srodničko udomiteljstvo za romsku djecu, no nakon povlačenja sredstava, projektne usluge podrške više nisu bile dostupne (D'Arcy i Brodie, 2015).

Romska djeca u sustavu institucionalne skrbi zastupljena su u većem broju od ostale djece, a šanse za njihovo posvajanje ili udomiteljstvo su smanjene, među ostalim i zbog predrasuda, stereotipa i stigmatizacije romske populacije općenito (Brooks, James i Barth, 2002; Morgan i Baron, 2011; Elijaš i Laklija, 2014; D’Arcy i Brodie, 2015; Šikić-Mićanović, Ivatts, Vojak i Geiger-Zeman, 2015). U mnogim europskim zemljama (npr. Češka, Mađarska, Bugarska, Rumunjska, Italija, Slovačka, itd.) zamjetan je nedostatak preventivnih mjera sustava socijalne skrbi koje bi odgovarale potrebama romskih obitelji u riziku i prevenirale izdvajanje djece, kao i usluga za romsku djecu i obitelji u zajednici (Vijeće Europe, 2012). Velikom broju romske djece u sustavu institucionalne skrbi također pridonose i neadekvatni uvjeti stanovanja, neplaniranje obitelji, siromaštvo te nizak obrazovni status roditelja zbog čega migriraju u potrazi za poslom te napuštaju djecu (D'Arcy i Brodie, 2015), bolest roditelja, odlazak u zatvor ili mlade majke napuštaju djecu (Vijeće Europe, 2012). Također, djeca se u institucionalnu skrb smještaju zbog zlostavljanja, socijalnih razloga (npr. siromaštva, beskućništva), obrazovanja, zdravstvenog stanja ili teškoća u razvoju, a razlog sporoj deinstitucionalizaciji romske djece leži u pristranosti stručnjaka prema institucionalizaciji (Daugherty Bailey i Schmidt, 2014). Europski sud za ljudska prava donio je presudu u kojoj je utvrđena diskriminacija institucionalizirane romske djece u Republici Češkoj, a vezana je uz njihovo uključivanje u skupine u kojima se radi prema prilagođenim i posebnim programima ne uzimajući u obzir njihove stvarne mogućnosti (Daugherty Bailey i Schmidt, 2014). 
Nakon što djeca uđu u sustav skrbi za djecu bez adekvatne roditeljske skrbi, često gube kontakt s roditeljima, iako oni zadržavaju sva roditeljska prava (D'Arcy i Brodie, 2015). Djeca koja su u udomiteljskim obiteljima imaju vrlo ograničen kontakt s obiteljima, a mnogoj djeci vrlo je teško ili čak nemoguće njegovati svoju kulturu i koristiti se romskim jezikom (Committee on the Elimination of Racial Discrimination, 2015). Romska se djeca na taj način dovode u situaciju da gube svoj etnički identitet i udaljavaju se od svoje kulture i ostalih Roma (Smith Rotabi i Hübinette, 2017, Sweeney i Matthews, 2017). U domovima za djecu zaposleno je vrlo malo pripadnika romske nacionalne manjine što je prepreka jačanju etničkog identiteta romske djece u institucionalnom smještaju (McGaughey i sur., 2012). Bilo da su djeca smještena u institucije ili udomiteljske obitelji, potrebno je održavati kontakt među djecom i njihovim obiteljima te etničkim skupinama kojima pripadaju (McGaughey i sur., 2012; Laklija i Sladović Franz, 2013, Smith Rotabi i Hübinette, 2017). O'Higgins (1993) upozorava da romska djeca, koja odrastaju izvan doticaja sa svojom kulturom, usvajaju vrijednosti i stavove prema Romima većinske populacije, a koji su često negativni, što dovodi do toga da djeca često nemaju mogućnost identifikacije s pozitivnim aspektima svoje kulture i da dijete svoj kulturni identitet s vremenom počinje doživljavati negativnim. S jedne strane, dijete se doživljava drukčijim u odnosu na zajednicu u kojoj živi, a s druge strane, romska ga populacija doživljava kao outsajdera zbog usvojenih vrijednosti i stila života većinske populacije. Negativan stav okoline, ali i negativan stav djeteta prema svojoj kulturi može dovesti do djetetove socijalne izolacije (Smith Rotabi i Hübinette, 2017) i manifestiranja društveno nepoželjna pa i kriminalna ponašanja (O'Higgins, 1993). U situacijama kada dođe do izdvajanja djeteta u udomiteljsku obitelj većinske populacije radi preveniranja ranije navedenoga, važno je omogućiti kontakte udomljene djece s romskom zajednicom putem romskih kulturnih centara ili udruga mladih Roma (Committee on the Elimination of Racial Discrimination, 2015). Daugherty Bailey i Schmidt (2014) ukazuju na potrebu tzv. kulturološke promjene u postupanju sustava socijalne skrbi koja bi dovela do zaštite prava romske djece na identitet $i$ kulturu, a koju bi ostvarili proširenjem usluga podrške djeci i njihovim roditeljima. Brojni autori (npr. McFadden i McNitt, 2008; UNICEF, 2008; Laklija, Blažeka Kokorić i Žabarović, 2016) ističu da se provođenjem edukacije o važnosti udomiteljstva i posvojenja romske djece polako mijenja njihov udio u populaciji djece u skrbi izvan vlastite obitelji.

\section{Udomiteljstvo djece pripadnika romske nacionalne manjine u Republici Hrvatskoj}

Vezano za udomiteljstvo djece pripadnika romske nacionalne manjine zamjetan je nedostatak podataka u službenim izvješćima nadležnog ministarstva budući da se ne objavljuju podatci o nacionalnosti djece ili udomitelja. lako se udomiteljstvo romske djece ne smatra specijaliziranim, radi se o specifičnoj skupini djece za koju, uz generalan nedostatak udomitelja za djecu na području Republike Hrvatske, postoje dodatne poteškoće pri pronalaženju udomiteljskih obitelji. Može se postaviti pitanje zašto je tako. Prema istraživanju Laklija, Blažeka Kokorić i Žabarović (2016), pripadnost romskoj manjini stručnjaci navode kao razlog teškoći u realizaciji posvojenja posebice djece starije dobi ili kada se pripadnost romskoj zajednici pojavljuje u kombinaciji s drugim rizicima (npr. zdravstvene teškoće, problemi u ponašanju djeteta i slično). Specifičnije, vezano za područje udomiteljstva, tj. spremnosti udomitelja da udome dijete određenih obilježja (Laklija, 2009), udomiteljice, sudionice istraživanja, izrazile su osrednju spremnost da udome dijete romske nacionalnosti 
( $M=3,78$, std $=1,497)$, tj. većina je odgovorila "niti nisam, niti jesam spremna udomiti dijete iz te kategorije". U spomenutom istraživanju, pri provjeri faktorske strukture Upitnika spremnosti udomitelja da udome dijete iz određene kategorije, čestica koja se odnosi na kategoriju djece romske nacionalnosti projicirala se na više komponenti i nije imala ni jednu značajnu saturaciju te nije korištena u daljnjoj analizi. Razlog tomu može biti davanje društveno poželjnih odgovora koji prikrivaju realnu spremnost udomitelja da udome dijete romske nacionalnosti. Zbog nedostatka romskih udomiteljskih obitelji te njihovim smještanjem u ustanove ili udomiteljske obitelji većinskog stanovništva, romska djeca gube doticaj s materinskim jezikom, identitetom i/ili vjerom. Navedeno je protivno djetetovim interesima i odredbama Konvencije o pravima djeteta ${ }^{2}$ koja obvezuje države stranke na poštivanje prava djeteta na očuvanje svojega identiteta, uključujući nacionalnost, ime i obiteljske odnose priznate zakonom. Marčac (2014) navodi da se udomitelji, koji nisu pripadnici romske nacionalne manjine, susreću s brojnim izazovima u odgoju djece romskog podrijetla jer ne poznaju dovoljno kulturu i tradiciju pa ni jezik, te da im je za taj aspekt, također, važna pomoć stručnih djelatnika centara za socijalnu skrb.

Kod nas postoji nekoliko dokumenata koji ističu važnost promocije i poticanja razvoja udomiteljske skrbi za romsku djecu, kao i udomiteljstva u kojem su pružatelji skrbi pripadnici romske nacionalnosti. Tako se u Nacionalnoj strategiji za prava djece u Republici Hrvatskoj za razdoblje od 2014. do 2020. godine (2014.; str 61,65) ističe, među ostalim, nužnost "razvijanja i čuvanja djetetova osjećaja identiteta (osobni, obiteljski, religijski, kulturalni, etnički) i pripadnosti za vrijeme smještaja u alternativnoj skrbi osiguravanjem skrbi na jeziku kojim se dijete služi“, „osiguravanja dosljedne primjene mjera stručne podrške i pomoći obitelji u skrbi za dijete vodeći se načelima međukulturalnosti te uvažavajući kulturni identitet djeteta i obitelji pri pružanju usluga”, kao i "promicanja i poticanja udomiteljskih obitelji za smještaj djece romske nacionalne manjine, povećanja broja romskih udomiteljskih obitelji koji zadovoljavaju zakonom propisane uvjete". Još neki dokumenti navode mjeru poticaja razvoja udomiteljske skrbi u romskim obiteljima, primjerice Nacionalni program za Rome Vlade Republike Hrvatske (2003) te Akcijski plan za provedbu Nacionalne strategije za uključivanje Roma (2012) koji ukazuje na važnost razvoja udomiteljske skrbi za romsku djecu ponajprije u romskim obiteljima te poticanja potencijalnih romskih obitelji na bavljenje udomiteljstvom. Međutim, važno je voditi računa i o kontekstu romske zajednice jer, kako se u tekstu strategije navodi, u romskim se zajednicama na udomljavanje djece u romske obitelji gleda kao na nov način "zarade" zbog čega se obiteljima "otimaju“ djeca. Na isto ukazuje i Vereš (2015a) navodeći da udomitelji Romi imaju iskustvo da ih se u romskim zajednicama optužuje za "etnobiznis", tj. za bogaćenje na račun njihove djece te ih se anonimno prijavljuje za navodnu nebrigu, zapostavljanje i loše postupke prema udomljenoj djeci. Vereš (2015b) navodi da su udomitelji Romi svjesni kako svojim angažmanom drugim Romima i javnosti šalju poruku da osobe romske nacionalnosti mogu kvalitetno brinuti o djeci, smanjujući pritom predrasude i stereotipe prema Romima te ujedno izražavajući i žaljenje jer se u javnosti premalo govori o Romima koji su odgovorni prema sebi, obitelji i društvu.

Žižak (2008) ukazuje na važnost udomiteljstva romske djece u romskim udomiteljskim obiteljima te predlaže edukacije i osnaživanje zainteresiranih obitelji (moraju zadovoljavati minimalne uvjete za bavljenje udomiteljstvom) u romskim naseljima, kao i važnost djelovanja obiteljskih centara u

2 Konvencija o pravima djeteta u članku 8. navodi sljedeće: „Države stranke se obvezuju da će poštivati pravo djeteta na očuvanje svoga identiteta, uključujući nacionalnost, ime i obiteljske odnose priznate zakonom, u što se neće nezakonito miješati. Kada su djetetu nezakonito uskraćene neke ili sve sastavnice identiteta, države stranke će osigurati odgovarajuću pomoć i zaštitu kako bi ono brzo uspostavilo ili obnovilo svoj identitet." (Državni zavod za zaštitu materinstva i mladeži, Zagreb, 2001). 
romskim naseljima te provođenja projekata vezanih uz udomiteljstvo romske djece koji mogu biti financirani iz domaćih i stranih izvora. U skladu s tim, Forum za kvalitetno udomiteljstvo i Ured UNICEF-a za Hrvatsku (Forum za kvalitetno udomiteljstvo, 2014) pokrenuli su projekt pod nazivom Razvoj udomiteljstva za djecu romske nacionalnosti Različito ih vidimo, jednako ih volimo u Međimurskoj, Varaždinskoj i Istarskoj županiji. Aktivnosti projekta uključuju edukaciju udomitelja (osobito unutar romskih zajednica) i stručnjaka, razmjenu iskustava, individualnu podršku udomiteljima i podizanje svijesti o udomiteljstvu.

Uzimajući u obzir ranije navedeno, zbog neistraženosti udomiteljske skrbi vezane za udomiteljstvo romske djece i dostupnosti udomitelja spremnih na udomljavanje romskog djeteta, kao i malog broja udomitelja pripadnika romske nacionalne manjine, odabrano je ovo područje istraživanja. Najveće romske zajednice prema Nacionalnoj strategiji za uključivanje Roma, za razdoblje od 2013. do 2020. godine (Vlada RH, 2012), nalaze se u Međimurskoj županiji, Gradu Zagrebu i Osječkobaranjskoj županiji, no može se reći da je romska manjina u Hrvatskoj prostorno raspršena. $S$ obzirom na brojnost udomitelja pripadnika romske nacionalne manjine, posebice udomitelja koji žive u romskim naseljima, odabrana je Međimurska županija u kojoj je i provedeno istraživanje. Prije prikaza istraživanja, u podnaslovu koji slijedi dan je kratak prikaz stanja udomiteljstva djece na području Međimurske županije, s posebnim naglaskom na romsku djecu.

\section{Statistički podatci o broju djece i udomitelja romske nacionalnosti u Međimurskoj županiji}

Udomiteljstvo romske djece u Međimurskoj je županiji razvijenije nego u drugim krajevima zemlje. Specifičnost je Međimurske županije u tome što je sve veći broj romskih obitelji koje se javljaju kao potencijalni udomitelji, no problem koji se javlja vezan je uz nedovoljnu obrazovanost romskih obitelji da bi dobile status udomitelja (Žižak, 2008). U Međimurskoj županiji u trenutku provođenja istraživanja bilo je ukupno sto pedeset troje udomljene djece, od čega je osamdeset šestero romske djece (četrdeset dvije djevojčice, četrdeset četiri dječaka). S obzirom na dob romske djece, njih dvadeset šestero djeca su predškolske dobi, a šezdesetero školske dobi, dok ih je dvadeset dvoje u statusu djece s teškoćama u razvoju. Najveći udio romske djece smještene u Međimurskoj županiji dolazi iz Međimurske županije, dok ih je osmero iz okolnih županija (jedno dijete iz Koprivničkokriževačke, četvero iz Varaždinske županije te troje iz Grada Zagreba).

Što se tiče udomiteljskih obitelji, prema internim podatcima Centra za socijalnu skrb Čakovec, 2016. na području Međimurske županije udomiteljsku djelatnost obavljalo je osamdeset udomiteljskih obitelji, od kojih je četrnaest obitelji romske nacionalnosti (udio od $19 \%$ u populaciji udomitelja). Od četrnaest romskih udomiteljskih obitelji, njih šest živi izvan romskih naselja, a osam u romskim naseljima. Svi udomitelji romske nacionalnosti, koji žive u romskim naseljima, imaju udomljenu djecu romske nacionalnosti. 


\section{Cilj istraživanja $i$ istraživačka pitanja}

Cilj je istraživanja dobiti uvid u iskustva pružanja udomiteljske skrbi udomitelja romske nacionalnosti za romsku djecu u romskim naseljima. U skladu s ciljem istraživanja, formirana su sljedeća istraživačka pitanja:

1. Koje su okolnosti motivirale udomitelje romske nacionalnosti na bavljenje udomiteljstvom?

2. Koji su to čimbenici koji utječu na pružanje udomiteljske skrbi u romskom naselju?

\section{Sudionici istraživanja i postupak prikupljanja podataka}

Istraživanjem se željela obuhvatiti cjelokupna populacija romskih udomitelja koji žive u romskim naseljima na području Međimurske županije, odnosno osmero udomitelja. U istraživanju je pristalo sudjelovati sedmero od ukupno osmero sudionika iz četiriju romskih naselja (pet muškaraca i dvije žene), u dobi od 38 do 48 godina; većina ih ima završeno osnovnoškolsko obrazovanje. Svi sudionici žive u bračnoj ili izvanbračnoj zajednici i imaju zajedničku djecu sa svojim bračnim ili izvanbračnim drugom. Raspon bavljenja udomiteljskom skrbi kretao se od deset mjeseci do 14 godina. Od sedmero sudionika samo se jedan bavio srodničkim udomiteljstvom. Petero je sudionika u trenutku istraživanja na smještaju imalo dvoje djece, jedan udomitelj imao je na smještaju jedno, a jedan četvero djece.

Istraživanje je provedeno u srpnju 2016. godine. Prije početka istraživanja pismenim putem zatražena je dozvola za provođenje istraživanja od ravnateljice Centra za socijalnu skrb Čakovec. Nakon dobivene suglasnosti, socijalna radnica zaposlena u Timu za udomiteljstvo CZSS-a telefonskim je putem stupila u kontakt sa sudionicima, objasnila im cilj i svrhu istraživanja te tražila njihovo dopuštenje za davanje njihova broja telefona istraživaču da bi se s njima moglo stupiti u kontakt i dogovoriti termin i mjesto provedbe intervjua. Od sudionika koji su izrazili suglasnost da ih se kontaktira telefonski, zatražen je pristanak za sudjelovanje $u$ istraživanju te je dogovoren termin $\mathrm{i}$ mjesto susreta. Podatci su prikupljeni putem polustrukturiranog intervjua u prostorijama CZSS-a te kućanstvima sudionika, prema pripremljenom protokolu s pitanjima. Pitanja su se odnosila na okolnosti odlučivanja na bavljenje udomiteljstvom, iskustvo pružanja udomiteljske skrbi općenito te s obzirom na život u romskom naselju, okolnosti koje su percipirane kao otežavajuće ili osnažujuće u bavljenju udomiteljstvom. Pitanja koja su postavljena sudionicima su:

— Kako ste se odlučili postati udomitelj/ica?

— Koje su Vas okolnosti potakle na to?

— Kako biste opisali svoje iskustvo pružanja udomiteljske skrbi?

— Što za Vas znači biti udomitelj u romskom naselju?

— Postoje li okolnosti koje Vam otežavaju bavljenje udomiteljstvom (vezane za vlastitu obitelj, biološku obitelj udomljene djece, sumještane u romskom naselju, uz sustav socijalne skrbi, obrazovni sustav)?

— Tko Vam pruža podršku u takvim situacijama? 
— Koje su okolnosti pomažuće, olakšavajuće pri bavljenju udomiteljstvom u romskom naselju?

— Imate li još što dodati vezano za svoja iskustva pružanja udomiteljske skrbi u romskom naselju?

Uz navedena pitanja udomiteljima su postavljena i dodatna pitanja radi produbljivanja dobivenih informacija. Intervjui su snimani diktafonom uz prethodno dopuštenje sudionika, a u prosjeku su trajali oko 30 minuta. Intervjuirani su na hrvatskom jeziku. Prije intervjua provjereno je razumiju li sudionici istraživanja hrvatski jezik te se nije pokazala potreba prevoditelja za romski jezik.

Osim upoznavanja sudionika sa svrhom istraživanja, sudionici su informirani o etičkim aspektima provedbe istraživanja, uključujući jamstvo povjerljivosti i anonimnosti u prikazu rezultata. Isto tako, poštivano je načelo dobrovoljnosti sudjelovanja, kao i pravo sudionika istraživanja da mogu ne odgovoriti na pitanja te u bilo kojem trenutku odustati od istraživanja.

\section{Metoda istraživanja i analize podataka}

U skladu s ciljem istraživanja odabran je kvalitativni pristup jer je svrha istraživanja dobiti dublje razumijevanje istraživane pojave (iskustva udomiteljstva Roma u romskim naseljima), tj. opisati i protumačiti iskustva, prikupiti nove spoznaje i steći znanje i razumijevanje bez polaznih pretpostavki (Milas, 2005). Dobiveni podatci obrađeni su postupkom tematske analize. Boyatzis (1998, prema: Žižak i sur., 2012) tematsku analizu definira kao proces identificiranja, analiziranja i izvještavanja prema temama koje se prepoznaju unutar dobivenih podataka. Tematska analiza podataka u ovom radu provedena je na semantičkoj razini koja se odnosi na kategoriziranje tema prema izjavama sudionika, a teme su definirane eksplicitno (Žižak i sur., 2012). Prema Mirosavljević (2015) razlog odabira tematske analize kao alata obrade podataka leži u njenoj fleksibilnosti, metodološkoj i teorijskoj; njome se nastoji sumirati podatke, ali ne nužno s ciljem stvaranja teorije. Tematska se analiza pokazala korisnom kod istraživačkih pitanja koja nemaju u fokusu socijalni proces i čimbenike koji na njih utječu, nego individualna iskustva sudionika. Za potrebe obrade podataka izradili su se transkripti razgovora iz snimljenih audiozapisa koji su se podvrgli kvalitativnoj analizi. Proces tematske analize uključuje: upoznavanje s podatcima, generiranje inicijalnih kodova, traženje tema, revidiranje tema, definiranje i imenovanje tema te pisanje izvještaja (Braun i Clarke, 2006).

\section{Rezultati i rasprava}

Rezultati su prikazani putem dvaju glavnih tematskih područja predviđenih istraživačkim okvirom:

1. okolnosti koje su djelovale motivirajuće na udomitelje za bavljenje udomiteljstvom

2. čimbenike koji utječu na pružanje udomiteljske skrbi u romskom naselju.

Navedene teme opisane su kategorijama i pojmovima koji se u daljnjem tekstu nadopunjuju izjavama sudionika istraživanja. 


\section{Okolnosti koje su motivirale romske udomitelje za bavljenje udomiteljstvom}

Udomitelje, pripadnike romske nacionalne manjine obuhvaćane ovim istraživanjem, na bavljenje udomiteljstvom motivirala je: želja za pružanjem primjerene skrbi djeci, postojanje uvjeta za bavljenje udomiteljstvom te iskustvo s udomiteljstvom.

\section{Tablica 1 Verbalizirane okolnosti koje su djelovale motivirajuće na romske udomitelje za bavljenje udomiteljstvom}

\begin{tabular}{|c|c|}
\hline Kategorije & Pojmovi \\
\hline \multirow{2}{*}{ Altruistični razlozi } & Želja za pružanjem pomoći djeci izbavljivanjem iz siromaštva i loših životnih uvjeta \\
\cline { 2 - 2 } & Želja za pružanjem obitelji djeci \\
\hline $\begin{array}{c}\text { Postojanje uvjeta za bavljenje } \\
\text { udomiteljstvom }\end{array}$ & Slobodan prostor u vlastitom domu za bavljenje udomiteljstvom \\
\cline { 2 - 2 } $\begin{array}{c}\text { Iskustvo s udomiteljstvom u vlastitoj } \\
\text { obitelji }\end{array}$ & Slobodno vrijeme za bavljenje udomiteljstvom \\
\cline { 2 - 2 } & Djeca iz proširene obitelji bila su u udomiteljskoj skrbi \\
\hline
\end{tabular}

Sudionici istraživanja naveli su aspekte intrinzične motivacije, uvjetovane altruističnim razlozima koji su rezultirali željom za pružanjem pomoći djeci, njihovu izbavljenju iz siromaštva i loših životnih uvjeta, tj. za pružanjem pomoći djeci u potrebi (...) Da i ja idem na neki način pomoći takvoj djeci... (1); (...) Htjela sam pomoći djeci, vidim jako puno djece koja žive u teškom stanju... da imaju život kak treba biti, da se školuje jer manje-više svi su bez škole... (3); (...) Jednostavno pomoći... neuhranjeno dijete, nikakav interes, nikakva briga, to je neopisivo... potaknula nas je ta bijeda, siromaštvo, glad i higijena... nismo to mogli gledati... (5); te želju za pružanjem obitelji djeci (...) Svako dijete treba obitelj... (2). Laklija (2011b) navodi da je motivacija za postajanjem udomitelja najčešće ona intrinzična, pri čemu se ističu altruistični motivi udomitelja za postizanjem promjena u životu udomljene djece, za pomaganjem i osiguravanjem stabilne okoline/obitelji za rast i razvoj djeteta (npr. briga za školovanje djeteta) te pružanjem ljubavi djetetu, što su spominjali i sudionici ovog istraživanja. Rezultati istraživanja Casteel (2015) na populaciji srodničkih udomitelja pripadnika romske nacionalnosti na području Grada Zagreba, također ukazuju na važnost altruističkih motiva, ali i motiv za popunjavanjem obiteljskog budžeta koji sudionici u ovom istraživanju nisu spomenuli.

Kao poticaj za bavljenje udomiteljstvom sudionici su spominjali postojanje uvjeta za bavljenje udomiteljstvom u njihovu domu, navodeći da imaju slobodan prostor i vrijeme za bavljenje djecom (...) Imali smo prostora, mogla se posvetiti toj udomljenoj djeci... (2); (...) Meni sve prazno... (5). Laklija (2011b) isto tako spominje i motive za udomiteljstvom koji se odnose na popunjavanje praznine, najčešće nakon odlaska iz kućanstva biološke djece udomitelja. I sudionici ovog istraživanja spominju postojanje praznog prostora i slobodnog vremena za brigu o udomljenoj djeci. Isto tako, navodili su iskustvo udomiteljstva u vlastitoj obitelji, odnosno primjere iz vlastite obitelji gdje je netko od članova obitelji bio ili je još uvijek udomitelj (...) Poticaj sam dobio od sina koji je udomitelj... (1); (...) Šogor mi je bio udomitelj... (2); (...) Od supruga mama je isto imala jedno dijete... mi smo vidjeli da je ona udomila, pa smo mi odlučili... (6); (...) Punica moja... ona zbog svoje dobi više nije mogla biti udomiteljica onda sam ja... samo radi toga jer smo živjeli s tim... pa šogor je isto bio udomitelj... (7); ili je dijete iz proširene obitelji bilo na smještaju u udomiteljskoj obitelji (...) Bila su od brata djeca udomljena... (4). Prethodno iskustvo s udomiteljstvom, u koje spada i poznanstvo s već postojećim udomiteljima, okolnosti su koje mogu djelovati motivirajuće za bavljenje udomiteljstvom (Laklija, 2011b). Prema navodima sudionika ovog istraživanja, važan motivirajući čimbenik je i iskustvo 
pružanja udomiteljske skrbi od članova obitelji ili smještanja u udomiteljsku skrb nekog člana iz njihove proširene obitelji. Sebba (2012) navodi kako 35 \% udomitelja za udomiteljstvo doznaje putem iskustva poznavanja neke udomiteljske obitelji, a $11 \%$ imalo je roditelje koji su pružali udomiteljsku skrb. Metcalfe i Humphreys (2002) navode da iskustvo poznanstva udomitelja, osim informiranja, utječe i na demistificiranje pojedinih oblika udomiteljstva, kao i udomljavanja pojedinih kategorija djece, što je ujedno i zadatak razvoja udomiteljstva za potrebe osiguravanja prava i dobrobit romske djece.

\section{Čimbenici koji utječu na pružanje udomiteljske skrbi u romskom naselju}

Iz izjava sudionika istraživanja, vezanih za čimbenike koji utječu na pružanje udomiteljske skrbi u romskom naselju, mogu se izdvojiti: okolnosti koje udomiteljima romske nacionalnosti otežavaju bavljenje udomiteljstvom te okolnosti koje ih osnažuju.

\section{Okolnosti koje udomiteljima romske nacionalnosti otežavaju bavljenje udomiteljstvom}

Prema dobivenim rezultatima, okolnosti koje udomiteljima romske nacionalnosti otežavaju bavljenje udomiteljstvom reakcije su sumještana na udomiteljstvo, ponašanje bioloških roditelja udomljene djece, ponašanje udomljene djece, utjecaji iz okoline i okolnosti života u romskom naselju.

Tablica 2 Okolnosti koje romskim udomiteljima otežavaju bavljenje udomiteljstvom

\begin{tabular}{|c|c|}
\hline Kategorije & Pojmovi \\
\hline \multirow{5}{*}{ Reakcije sumještana na udomiteljstvo } & Isticanje materijalne koristi za udomitelje \\
\hline & Zavist sumještana \\
\hline & Izostanak podrške sumještana \\
\hline & Prijave udomitelja centru za socijalnu skrb \\
\hline & Neprimjereni komentari s namjerom ponižavanja \\
\hline \multirow{4}{*}{ Ponašanje bioloških roditelja djece } & Neodgovorno ponašanje roditelja pri ostvarivanju kontakta s djetetom \\
\hline & Otpor roditelja djece prema udomiteljima \\
\hline & Prijetnje roditelja udomljene djece udomiteljima \\
\hline & Ponašanje roditelja pod utjecajem sumještana \\
\hline \multirow{5}{*}{ Ponašanje udomljene djece } & Nedostatak socijalizacije djece \\
\hline & Problemi u ponašanju djeteta \\
\hline & Doživljena trauma djeteta \\
\hline & Utjecaj bioloških roditelja na djecu \\
\hline & Utjecaj braće i sestara na djecu \\
\hline \multirow{2}{*}{ Život u romskom naselju } & Buka u naselju \\
\hline & Mogući utjecaj sumještana na djecu \\
\hline
\end{tabular}

Što se tiče reakcija sumještana na udomiteljstvo, sudionici su naveli zlonamjerno isticanje sumještana da to čine zbog materijalne koristi, tj. bogaćenja na račun skrbi za dijete (...) Da je to iz nekakvih materijalnih pobuda... komentirali su šta to meni treba i zašto ja to radim sobzirom da sam se na neki način materijalno osigurao, imam kuću, imam zadovoljavane potrebe života... govorili su: pa znaš ti koliko je to plaćeno... misle si, joj taj sad mlati pare... (2); (...) Svi samo pričaju da je za lovu... za te novce svi pitaju, sad ćeš si ono napraviti, znaš ono, kredit ono... svi prigovaraju, a tu bijedu svi gledaju... (5); (...) Da smo se obogatili, da smo sve stvorili od te djece... da se ja obogaćujem, da imam novce... (6). Udomitelji Romi kao otegotnu okolnost u bavljenju udomiteljstvom navode ljubomoru 
sumještana (...) Ljubomorni su ne samo zbog tog što sam udomiteljica... oni su ljubomorni, ako vide da nešto radite, gradite... zavidni su... (3); (...) S romskim ženama, znaš kakve su, ogovaraju te... (4); (...) Imam problema otkad sam posto udomitelj zbog jalnosti... jal vlada... (6); i izostanak podrške sumještana (...) Na sastanku u Zagrebu na okruglom stolu, tamo se digao naš poglavica i onda nas počeo ocrnjivati, zašto smo mi Romi udomitelji... on nas još gazi... (6); (...) Nemamo potporu naših sumještana Roma, čak ni naših predstavnika... jer oni to doživljavaju, misle da mi to gledamo kroz neke financije... (7). Što se tiče prijava Centru za socijalnu skrb, naveli su da dolazi do anonimnih prijava sumještana (...) Kako je mogao biti udomitelj, a nema gradsku vodu... bilo je toga... (1); (...) Prva prijava je bila odmah prve godine... ja rješavam u kancelariji i zvoni socijalnoj radnici telefon, dolazi dojava, rekli su joj da su djeca zapuštena, gladna, bosa, svašta ono najgore... ja sam bila baš tamo... nismo sigurni tko je to dojavio... uvijek su takve dojave bile... mislim da mi imamo najviše dojava, jer smo bili prvi... oni su čak saznali za članak da udomitelj mora biti u radnom odnosu... ja sam prošle godine bio pod ugovorom, šest mjeseci preko javnih radova, oni su već dojavili za dva-tri dana u centru da ja više ne radim... jer su znali da kao moram imati radni odnos... (6); (...) Imali smo anonimnu prijavu da djecu ne šaljemo redovito u školu, da su prljava... (7); ali i prijava udomitelja međusobno (...) Međusobno se prijavljuju udomitelji... (5); (...) Udomitelji koji su obavljali isto što i ja, otišli su u centar i tužakali druge udomitelje... (7). Sudionici istraživanja, među reakcijama sumještana koje doživljavaju otežavajućim, navode i neprimjerene komentare koji po svojem sadržaju ponižavaju udomitelje ili djecu u udomiteljskoj skrbi (...) Srde se... misle pa šta ih ne držite u dvorištu... ja se nikad ne bi ponizio da uzdržavam tuđe dijete... tuđi drek da bu on brisal... (2); (...) Pa rekli su, pa šta će ti djeca, pa možeš napraviti, da oprostite, imaš ženu, ovo ono... (5).

Literatura ukazuje da je jedan od izvora poteškoća s kojima se susreću udomiteljske obitelji nošenje sa stavovima okoline prema udomiteljstvu te da obilježja socijalne okoline udomitelja (lokalna zajednica i susjedstvo) utječu na ishode udomiteljstva (Kregar, 2006; Laklija, 2011a). Iz izjava sudionika zamjetno je da u romskom naselju sumještani na udomiteljstvo gledaju kao na izvor zarade radi popunjavanja obiteljskog budžeta te da ni od mjesnih poglavica nemaju podršku. Vereš (2015a) također ukazuje na stav sumještana i optuživanje udomitelja za tzv. „etnobiznis”, bogaćenje na račun skrbi za udomljeno dijete. Nadalje, sudionici su spomenuli da im i prijave Centru za socijalnu skrb otežavaju bavljenje udomiteljstvom. Isto navodi Vereš (2015a) opisujući iskustva romskih udomitelja koji žive u romskim naseljima da ih se često zbog zavisti anonimno prijavljuje za navodnu nebrigu, zapostavljanje i loše postupke prema udomljenoj djeci. Zanimljivo bi bilo u budućim istraživanjima usmjeriti se na sadržaj tih prijava i postupanja socijalnih radnika. Npr. iz jedne od izjava zamjetno je da i sam udomitelj navodi da nema pristup vodovodu te se dovodi u pitanje zadovoljava li ta obitelj uvjete za bavljenje udomiteljstvom. S obzirom na komentare koje udomitelji navode, tj. da im je cilj poniziti udomitelje, bilo bi važno istražiti i kojim su komentarima izložena djeca koja su na smještaju u udomiteljskim obiteljima u romskom naselju.

Od ponašanja bioloških roditelja djece, koja im otežavaju udomiteljstvo, sudionici spominju neodgovorno ponašanje roditelja vezano za ostvarivanje kontakta s djetetom, pri čemu navode nedolaženje roditelja na kontakt s djetetom (...) Ona uopće ne dolazi... sve rjeđe zove... (1); (...) Mi smo dolazili, ona nije došla... (3); ili dolazak na kontakt pod utjecajem sredstva ovisnosti (...) Dođe mi pijana... rekla sam joj par puta već, ali ne možeš ti osobi koja pod alkoholom nekaj govoriti... ako si došla kod svog djeteta, budi u dvoru kod mene, a ne kod dućana de pije... to ne dozvoljavam... (4); 
(...) Bila je pijana, ona radi nekakve stvari koje ne bi smjela... nema muža, danas je tu, sutra je u Bosni, prekosutra je ono... tu se radi i droga... ona je odnijela malu... jer je bila kao pijana... (5). Sudionici istraživanja kao otežavajuće čimbenike navode i otpore roditelja prema udomiteljima (...) Doživljavaju nas kao neprijatelje... kao da smo mi krivi što su njima oduzeli djecu... prilikom susreta vidimo da su dosta neprijateljski raspoloženi prema nama, ne žele komunicirati kao normalni ljudi nego uvijek je tu ljutnja nekakva, represija... dosta je tu otpora... (2); (...) Od početka nije htjela da smo mi, da bude u romskom naselju... nije htjela dati djecu... (3); (...) Roditelji su nas gledali kao da mi oduzimamo tu djecu, da centar na naš zahtjev oduzima i nama smještava... onda je problem kontakt... (7); prijetnje roditelja djece (...) Onda nas provociraju, prijete, prijete verbalnim... vi ste krivi, vi bute nastradali, ja ću vas naći negdje, mi ćemo se obračunati na neki način... (7); te ponašanja roditelja pod utjecajem sumještana (...) Ne žele ništa potpisivati, suglasnosti za školske izlete... ljudi iz naselja im govore da ne smiju ništa potpisivati jer bi im trajno oduzeli djecu... (2).

Rezultati ovog istraživanja, vezano uz ponašanja bioloških roditelja djeteta u udomiteljskoj skrbi, u skladu su s istraživanjima (Sanchirico i Jablonka, 2000; Družić Ljubotina, Jelača i Kletečki Radović, 2005) u kojima udomitelji navode da su u nekim slučajevima roditelji nezainteresirani za svoju djecu dok su drugi, pak, agresivni u komunikaciji i s djecom i s udomiteljima. Što se tiče ponašanja roditelja, u romskim naseljima prisutan je problem alkoholizma (Elijaš i Laklija, 2014) koji su sudionici ovog istraživanja spomenuli kao otežavajuću okolnost pri susretima djeteta i bioloških roditelja, kao i ovisnosti o drogama. Brojni autori (npr. Sanchirico i Jablonka, 2000; Heller, Smyke i Boris, 2002; DeGarmo, 2014) spominju odnos udomitelja i bioloških roditelja udomljenog djeteta kao jedan od izvora teškoća s kojima se udomitelji susreću, a što su spomenuli i sudionici u ovom istraživanju primjerima otpora bioloških roditelja udomljene djece te prijetnjama udomiteljima. Sudionici ističu i nezadovoljstvo komunikacijom s biološkim roditeljima koja je u potpunosti izostala ili je iznimno rijetka. Rezultati ukazuju na potrebe podrške udomiteljima u ostvarivanju kontakta s djetetovim roditeljima. Iz izjava sudionika, može se zaključiti da roditelji zbog nerazumijevanja funkcioniranja sustava te pod utjecajem sumještana, u strahu da ne ostanu bez roditeljske skrbi, na štetu djeteta odbijaju sudjelovati, tj. davati suglasnosti za pojedine djetetove aktivnosti (npr. odlazak na izlet). Nadalje, navedeno se može objasniti i činjenicom da Romi općenito imaju nisku pismenost i nedovoljno poznaju hrvatski jezik (Novak, 2004) pa se i tome može pripisati otpor roditelja djece u potpisivanju određenih suglasnosti jer sami nisu dovoljno pismeni da pročitaju i razumiju što potpisuju. Također, iz izjava sudionika može se prepoznati i stav nepovjerenja stanovnika romskih naselja prema sustavu socijalne skrbi jer se udomitelji percipiraju kao oni na čije se prijave oduzimaju djeca i smještaju u njihove obitelji. Povežemo li to s ranijim nalazom vezanim za učestalost prijava sumještana i udomitelja međusobno, moglo bi se zaključiti da od tuda i proizlazi takav roditeljski stav. No, to nije nalaz ovog istraživanja te bi to trebalo istražiti u kontaktu s biološkim roditeljima. Istraživanja ukazuju i na neizbježan sukob koji proizlazi iz nužnosti suradnje udomitelja s biološkim djetetovim roditeljima, a uz istovremenu odbojnost i otpor prema njima te pojavu projekcije; naime, biološki roditelj ljutnju prema socijalnim radnicima projicira na odnos $s$ udomiteljima (Whiting i Huber, 2007). Sve to ukazuje na važnost educiranja kako udomitelja, tako i roditelja o samom sustavu, njihovim pravima, ali i odgovornostima u cilju zaštite dobrobiti djeteta.

Okolnosti koje otežavaju bavljenje udomiteljstvom su uz ponašanja bioloških roditelja udomljene djece i ponašanja udomljene djece, tj. njihove poteškoće $u$ adaptaciji te poteškoće vezane uz 
funkcioniranje djeteta u obitelji udomitelja, što je u skladu s brojnim istraživanjima (npr. Heller, Smyke i Boris, 2002; Miron i sur, 2013). Vezano uz ponašanje udomljene djece sudionici navode da im poteškoće u bavljenju udomiteljstvom stvaraju i neka obilježja ponašanja i prethodna iskustva života/odrastanja djeteta. Udomitelji izdvajaju nedostatak socijalizacije djeteta (...) Oni nisu znali što je to WC, bojali su se... (1); (...) Bojala su se vode, nisu znala što je to vodokotlić... dok sam ih kupala, cvilili su... on nije znao držati žlicu, vilicu, nož u rukama, ama baš ništa, on se umarao dok je jeo... on nije znao hrvatski... (3); manifestiranje problema u ponašanju (...) Čaša mora biti tu, on će je namjerno srušiti... (5); (...) Bilo je teško s njim, imao je dosta tih mana oko ponašanja... potkradanja... (7); te iskustvo djeteta vezano uz doživljene traume u obitelji (...) Ona je imala ožiljke po očima, gasila joj je čikove po rukama, u oku... (1); (...) To su tragedije što je govorio, što su oni doživljavali... oni kad meni kažu, ja se naježim... trauma za njih... (3). Utjecaji okoline na dijete koji otežavaju udomiteljstvo, prema navodima sudionika, utjecaji su bioloških roditelja na udomljeno dijete (...) Neprirodno se ponaša dok dolazi iz biološke obitelji, plače, hoće nazad ići... razgovarao sam i sa socijalnom radnicom i sa svim njima... valjda je to ono oduševljenje sa roditeljima i onda mu sve daju po volji, sve mu kupuju... a mali kak mali, možete ga kupiti... (2); (...) Tata mu obećava brda i doline... obećavaju na kontaktima svašta, budete se vratili doma, mi imamo za vas ovo već spremno, ovakve igračke, onakve sobe, onda se tu djeca kolebaju... (7); te utjecaj braće i sestara udomljene djece (...) Ima polusestru, ta polusestra ju je u četiri-pet navrata zaustavila na putu do škole... i onda je iskoristila priliku i nagovara ju na gluposti... daj uzmi stričeku novčanik, napravi ovo, ono... tako polusestra ju je i nagovorila da priča o nama sve najlošije i ona je to pričala što nije bilo istina... priznala je kasnije da ju je sestra nagovarala na takve stvari... (7).

Što se tiče djece, sudionici su naveli da im poteškoće stvaraju djeca s problemima u ponašanju, što je prepoznato i u literaturi (Laklija, 2011a) gdje se spominje da djeca s problemima u ponašanju mogu udomiteljima predstavljati poseban izazov u brizi za zadovoljavanje njihovih potreba. Djeca koja dolaze u udomiteljske obitelji mogu imati različite složene, socijalne, emocionalne i bihevioralne poteškoće koje im otežavaju prilagodbu na novu obiteljsku sredinu (Škrbina, 2010). Isto tako, sudionici su spomenuli da su djeca proživjela traumatske događaje u svojoj primarnoj obitelji. Poznato je da neka djeca, smještena u udomiteljske obitelji u Hrvatskoj, imaju iskustvo dugotrajne izloženosti višestrukim stresnim događajima od alkoholizma u obitelji, tjelesnoga i psihičkog zlostavljanja te zanemarivanja, a često su iz svojih primarnih obitelji izdvojena prekasno da bi se spriječile posljedice vezane uz njihovo psihofizičko funkcioniranje (Kletečki Radović i Kregar Orešković, 2005). Nadalje, udomitelji navode i tzv. negativan utjecaj kontakta djeteta s roditeljima, na ponašanje djeteta nakon završetka kontakta. Dugan (2014) navodi da djeca nakon susreta s roditeljima često mijenjaju svoje ponašanje zbog obnove sjećanja i emocija koje se vežu za gubitak i tugovanje, ali i nerealnih roditeljskih obećanja koja se ne mogu ostvariti, a koja kod djece stvaraju lažnu nadu (nerealistično govore o odlasku od udomitelja i povratku roditeljima, sklona su idealizirati roditelje i nerealistički prihvaćati njihov utjecaj i sl.).

Prema navodima udomitelja, život u romskom naselju predstavlja također jednu od okolnosti koja otežava bavljenje udomiteljstvom. Kao otežavajuće okolnosti sudionici navode buku u naselju (...) Buka, muzika... (5); i moguć utjecaj sumještana i njihova načina života na udomljenu djecu (...) Moja djeca se ne druže sovima iz naselja, ja to ne dam... (1); (...) Ne dozvoljavamo im nekakvo udaljavanje tipa da odlaze u naše naselje... (2); (...) Jer tu su djeca koja već puše od male noge, većinom već alkohol 
troši... jer znate, djeca kopiraju roditelje... jer ti vidiš način života Roma i znaš s kim se tvoje dete može družiti, moja deca se ne druže s bilo kojima... (4); (...) Kod nas je u mjestu uvijek alkohol, droga... (5). Prema Šućur (2004) u romskim naseljima prisutan je već spomenuti problem alkoholizma te razni oblici društveno neprihvatljiva ponašanja. U tom kontekstu, sudionici ovog istraživanja rizik za dijete vide u početku pušenja i konzumiranju alkohola već u osnovnoj školi kao rezultat učenja po modelu roditelja i drugih sumještana, a isto tako i rizik zloupotrebe raznih droga. Kako se iz nekih izjava može vidjeti, dio udomitelja djetetu brani odlaženje u naselje ili druženje s djecom iz naselja iz straha od mogućih negativnih utjecaja. Tu se postavlja pitanje koliko je, u skladu s navodima sudionika, vezano uz percipirane rizike za dijete u nekim romskim naseljima, zaista u najboljem djetetovu interesu to da bude smješteno u obitelji udomitelja u romskom naselju radi osiguravanja prava djeteta na očuvanje religijskoga, kulturološkog i/ili etničkog identiteta.

\section{Okolnosti koje osnažuju udomitelje romske nacionalnosti u bavljenju udomiteljstvom}

Sudionici istraživanja kao okolnosti koje ih osnažuju tijekom bavljenja udomiteljstvom navode podršku udomiteljima, emotivne "efekte" udomiteljstva te život u romskom naselju.

Tablica 3 Okolnosti koje osnažuju romske udomitelje u bavljenju udomiteljstvom

\begin{tabular}{|c|c|}
\hline \multicolumn{1}{|c|}{ Kategorije } & Pojmovi \\
\hline \multirow{4}{*}{ Podrška } & Podrška vlastite obitelji \\
\cline { 2 - 2 } & Podrška prijatelja i sumještana \\
\cline { 2 - 2 } & Podrška socijalnih radnika \\
\cline { 2 - 2 } & Podrška neprofitnih organizacija \\
\cline { 2 - 2 } & Podrška obrazovnog sustava \\
\hline \multirow{2}{*}{ Emotivni „efekti" udomiteljstva } & Emotivna ispunjenost koju pruža bavljenje udomiteljstvom \\
\cline { 2 - 2 } & Povezanost s udomljenom djecom \\
\hline \multirow{2}{*}{ Život u romskom naselju } & Blizina djeteta romskoj kulturi i jeziku \\
\cline { 2 - 2 } & Način života u romskoj zajednici \\
\cline { 2 - 2 } & Budućnost djece u romskom naselju \\
\hline
\end{tabular}

Sudionici su navodili da ih osnažuje podrška obitelji (...) Većinom je to podrška, razgovor sa suprugom... (2); (...) Npr. baka, braća, rodbina... (5); (...) Obitelj... (7); prijatelja i sumještana (...) Ljudi u selu, Hrvati, a i Romi... (2); (...) Naši prijatelji... (3); (...) Pozitivno kaj su mi rekli... bolje da si ti nego neko drugi, daju mi potporu malo, kao u redu je... (4); socijalnih radnika (...) Onda se socijalna radnica zauzela za nas... imao sam podršku od svih socijalnih radnika... (6); (...) Imamo potporu centra... (7); neprofitnih organizacija (...) I na tim nekakvim sastancima udomitelja znamo govoriti o svojim iskustvima, lakše nam je kad to nekome nešto govorimo i jednostavno tam dobite podršku i nekakvu ljudsku riječ... (2); (...) Imamo udrugu udomitelja... njihovu podršku moralnu... (7); medijska podrška (...) Hvalili su nas baš preko medija, novina... (7); te podrška obrazovnog sustava (...) Razgovarao sam s ravnateljem, sve je razumio... prihvaćeni su... (1); (...) U školi i to, svakodnevno kolege i u centru za odgoj isto... (2). Sudionici istraživanja navode razne izvore socijalne podrške. Spomenuli su podršku obitelji što, prema literaturi, predstavlja primarni i najčešći izvor socijalne podrške (Dobrotić i Laklija, 2012), podršku prijatelja, podršku sumještana, podršku neprofitnih organizacija, medijsku podršku te podršku socijalne skrbi i obrazovnog sustava. Slično nalazima ovog istraživanja i Vereš (2015b) ukazuje na zadovoljstvo udomitelja romske djece u Međimurskoj županiji s prihvaćanjem 
djece romske nacionalnosti u svojoj okolini te u osnovnim i srednjim školama. Važnost socijalne podrške ogleda se u tome da socijalna podrška može ublažiti negativan utjecaj stresa, poboljšavajući sposobnost osobe za suočavanje sa stresorom, što znači da se osoba može djelotvornije suočiti s povećanim zahtjevima određene situacije kad su joj dostupni drugi ljudi koji joj pružaju različite oblike pomoći, naročito emocionalne (Pećnik i Raboteg Šarić, 2005). Ova teorijska postavka objašnjava značajnost socijalne podrške pri suočavanju s okolnostima koje otežavaju udomiteljstvo u romskim naseljima.

Kao čimbenik koji ih osnažuje udomitelji navode i emotivne "efekte" udomiteljstva, tj. emotivnu ispunjenost koju pruža bavljenje udomiteljstvom (...) Jer ja znam da sam nekome pomogo... to je ljubav... (5); (...) Mogu reći da sam uspio... ja ću biti zahvalan... (6); (...) To mi je najveća nagrada u životu... (7); te bliski odnosi u obitelji, tj. povezanost s udomljenom djecom (...) Ja sam njegova majka... on mene zove mama... (3); (...) Djeca govore meni tata, njoj mama... govori da mu je brat... smatra ga kao brata... (6). Spomenuti emotivni "efekt" udomiteljstva možemo povezati s njihovom intrinzičnom motivacijom, konkretnije, altruističnim motivom za bavljenje udomiteljstvom. lako se u kontekstu ovoga istraživanja ne može ništa zaključiti o povezanosti motivacije udomitelja i njihova zadovoljstva u ulozi udomitelja, MacGregor i suradnici (2006) navode da je intrinzična motivacija udomitelja u visokoj korelaciji s njihovim zadovoljstvom udomiteljstvom i zadržavanjem u ulozi udomitelja. Iz izjava udomitelja zamjetna je važnost koju udomitelji pripisuju emocionalnom polju, vezano uz stvaranje odnosa privrženosti s udomljenim djetetom, ostvarenu bliskost s djetetom. $S$ druge strane, izazov s kojim se udomitelji susreću odnosi se na stvaranje mogućnosti za razvoj privrženosti između djeteta i udomitelja uz istovremeno uvažavanje i zadržavanje odnosa privrženosti i identifikacije s biološkim roditeljima. Socijalni radnik u tom kontekstu treba pomoći i udomiteljima i djetetu u nošenju s emocijama vezanima za biološku obitelj djeteta. Udomitelje treba educirati o načinu kako će im se dijete obraćati. Naime, udomitelji, uzimajući u obzir činjenicu da nemaju roditeljsku skrb za udomljeno dijete te da ono ima biološke roditelje, ne bi trebali poticati ni dopuštati da im se dijete obraća s "mama" ili s "tata" (Dugan, 2014). Udomitelji nisu djetetovi roditelji te u tom kontekstu treba problematizirati (u kontaktu s njima tijekom edukacije, ali i tijekom pružanja udomiteljske skrbi) koji su učinci na dijete i njegovu biološku obitelj nazivanjem udomitelja mamom ili tatom.

lako su sudionici život u romskom naselju prepoznali kao okolnost koja otežava bavljenje udomiteljstvom, navode je i kao olakšavajuću okolnost zbog važnosti očuvanja kulture, jezika, ali i budućnosti udomljene djece. $U$ tom kontekstu, sudionici istraživanja ističu blizinu djeteta romskoj kulturi i jeziku (...) Zbog očuvanja kulture i jezika, svih tih nekakvih dobrih strana... (2); (...) Kultura nas veže... (5); (...) To je naša tradicija, naša kultura... jezik... da bude prednost u romskom naselju... moraju znati materinji jezik, to se ne može samo tako ukinuti... (6); (...) Njima je ipak lakše imati prijatelje Rome, ipak zbog jezika... (7); način života u romskoj zajednici (...) Djeca su puno zadovoljnija biti u romskom naselju, družiti se jer mi smo naučeni živjeti u družini... naša djeca su naučena živjeti u društvu... (6); te budućnost udomljene djece u romskom naselju koja se odnosi na povratak djece u obitelj (...) Nakon nekoliko godina djeca se ipak vraćaju kući, ipak dom je dom... (3); (...) Kad navršavaju 18 godina normalno opet natrag u naselju... (5). Sudionici ovog istraživanja su, kao i udomitelji Romi u istraživanju Vereš (2015a), iskazali da za romsku djecu smatraju boljim odrastanje u romskim 
udomiteljskim obiteljima jer na taj način ostaju u svojoj kulturi, koriste se materinskim jezikom te se osjećaju sigurnijim u tom okruženju.

\section{Ograničenja istraživanja}

Spoznaje dobivene ovim istraživanjem treba sagledati u kontekstu istraživanja, odnosno imajući u vidu istraživački kontekst i njegova ograničenja. Jedno od metodoloških ograničenja vezuje se uz činjenicu da su sudionici istraživanja vezani isključivo za jednu regiju te bi bilo dobro proširiti broj sudionika u daljnjim istraživanjima na cijelo područje Hrvatske s obzirom na postojanje regionalnih razlika u udomiteljstvu na području Republike Hrvatske. Kao posrednike u dolaženju do sudionika istraživanja, korisno bi bilo uključiti udruge da bi se smanjilo davanje socijalno poželjnih odgovora koje su sudionici davali možda iz razloga što su ih kontaktirale socijalne radnice iz nadležnog centra za socijalnu skrb. Također, na odgovore sudionika u smjeru davanja socijalno poželjnih odgovara moglo je utjecati i samo mjesto intervjuiranja. Naime, dio intervjua proveden je u prostoru Centra za socijalnu skrb, a dio u udomiteljskim obiteljima. Ograničenja koja proizlaze iz provedenih polustrukturiranih intervjua odnose se na mogućnost da nisu obuhvaćeni svi relevantni aspekti postavljenih istraživačkih pitanja te bi ih u budućim istraživanjima trebalo produbiti. Tijekom nekih intervjua bilo je potrebno provjeriti razumijevanije postavljenih pitanja sudionicima istraživanja. Prije intervjua provjereno je razumiju li sudionici hrvatski jezik te se nije pokazala potreba prevoditelja za romski jezik. No, ostaje otvoreno pitanje, je li moguće ograničenje vezano uz razumijevanje pitanja ili mogućnost izražavanja na hrvatskom jeziku utjecalo na prikupljene podatke, tj. na sadržaj, razinu dobivenih uvida i duljinu intervjua. $U$ budućim bi se istraživanjima ovom aspektu trebala posvetiti posebna pozornost. Intervju je provodila osoba koja dolazi iz regije u kojoj je istraživanje provedeno te koja govori međimurskim dijalektom. $U$ odnosu na metodu/tehniku provedbe istraživanja, odnosno primjenu polustrukturiranog intervjua, u idućem istraživanju bilo bi važno primijeniti i druge metode i tehnike istraživanja, npr. fokusne grupe sa sudionicima, analize slučajeva, itd. U odnosu na poziciju istraživača, vodilo se računa da istraživači nisu ni na koji način povezani sa sudionicima, kao i o važnosti osvještavanja istraživačeve naklonosti i pozicije u odnosu na predmet istraživanja da bi se prevenirao njihov utjecaj na proces prikupljanja podataka, ali i interpretaciju dobivenih podataka. U cilju osiguravanja vjerodostojnosti, istraživanje je proveo nepristran istraživač. U cilju provjere dosljednosti, tijekom obrade podataka, pojmovi, kategorije i teme bile su raspravljene iz dviju istraživačkih perspektiva.

\section{Zaključna razmatranja}

Doprinos ovog istraživanja predstavlja orijentacija na korisničku perspektivu udomitelja romske nacionalnosti. Uvid u dobivene rezultate omogućava bolje razumijevanje iskustva udomitelja Roma u romskim naseljima te temeljem toga planiranje daljnjih aktivnosti veznih kako za podršku obiteljima (biološkim i udomiteljskim) i djeci u udomiteljskoj skrbi, tako i regrutiranje i educiranje novih obitelji. Rezultati dobiveni ovim istraživanjem pokazali su da je poticaj udomiteljima, pripadnicima romske nacionalne manjine za bavljenje udomiteljstvom, ponajprije bila želja za pružanjem primjerene skrbi potrebitoj djeci koju doživljavaju kao način njihova izbavljanja iz siromaštva i loših životnih uvjeta te želje za pružanjem pomoći obitelji. Kao ostale poticaje navode postojanje uvjeta 
za bavljenje udomiteljstvom koji se odnose na posjedovanje slobodnog prostora i vremena za skrb o djeci, kao i iskustvo udomiteljstva u vlastitoj obitelji. Kao okolnosti koje im otežavaju bavljenje udomiteljstvom, sudionici su navodili razne reakcije sumještana na njihovo bavljenje udomiteljstvom (optuživanje za stjecanje materijalne koristi, zavist, izostanak podrške, prijave CZSS-u te neprimjerene komentare), ponašanje bioloških roditelja djece (neodgovorno ponašanje pri ostvarivanju kontakata s djetetom, otpor i prijetnje prema udomiteljima te ponašanja pod utjecajem sumještana), ponašanja djece (nedostatna socijalizacija, problemi u ponašanju, nošenje s traumom te utjecaj roditelja, braće i sestara na dijete) i život u romskom naselju (buka u naselju i moguć negativan utjecaj na dijete). Upravo ti čimbenici daju jasne smjernice na kojim aktivnostima treba biti naglasak sustava socijalnih politika, u skladu s radom spomenutih strategija i dokumenata, ali i stručnjaka CZSS-a, civilnog sektora i nadležnog Ministarstva. Nadalje, dobiveni rezultati u istraživanju ukazuju na neka potencijalno nova istraživačka područja, teme i ciljeve koje bi bilo vrijedno produbiti (npr. optužbe za tzv. „etnobiznis", stavovi starješina/poglavica u romskim naseljima prema udomiteljstvu, prijave CZSS-u, doživljaj udomiteljstva iz perspektive roditelja i djece i sl.).

Osnažujuće okolnosti u pružanju udomiteljske skrbi za sudionike predstavlja socijalna podrška, tzv. emocionalni "efekti" udomiteljstva na udomitelje kao i život u romskom naselju koji spominju i kao okolnost koja ih osnažuje upravo zbog kulture, jezika koji djeca dijele sa svojim sumještanima te zbog osjećaja pripadnosti udomljene djece romskoj zajednici. Rezultati ukazuju na prepoznatu važnost zaštite kulturnog identiteta djeteta te potrebu informiranja i upoznavanja Roma s udomiteljstvom, s uvjetima koje je potrebno zadovoljiti da bi postali udomiteljima, pozitivnim primjerima udomitelja te životnim pričama udomljene romske djece, a sve u namjeri senzibiliziranja i motiviranja romskih obitelji na bavljenje udomiteljstvom i unapređenje kvalitete skrbi za djecu. Način kojim bi se to moglo postići organiziranje je javnih tribina u romskim naseljima i javnim servisima koji su dostupni romskim obiteljima. Također, važno je educirati pripadnike romske nacionalne manjine o tome kako sustav udomiteljstva funkcionira i informirati roditelje djece koja su izdvojena iz obitelji o njihovim pravima i odgovornostima, kao i o njihovoj ulozi u životu djeteta nakon njegova izdvajanja. Također, suradnjom nadležnog ministarstva, centara za socijalnu skrb, međunarodnih organizacija i udruga u području udomiteljstva i šire, nužno je romskim udomiteljskim obiteljima pružiti podršku i edukaciju u nošenju sa stavovima okoline, ponašanjima roditelja i djeteta te drugih izazova vezanih uz pružanje udomiteljske skrbi, a sve radi osiguravanja zaštite i kvalitete skrbi za udomljeno dijete. U dijelu promicanja udomiteljstva, rezultati ukazuju koliko je važno uspostaviti kontakt s poglavicama u romskim naseljima kao autoritetima, ali i udruženjima Roma.

Iz podataka dobivenih ovim istraživanjem ne doznajemo mnogo o tome kako udomitelji pružaju udomiteljsku skrb i/ili kakvo je njihovo iskustvo pružanja udomiteljske skrbi (npr. na relaciji odnosa udomitelj — dijete, utjecaj na njihovu obiteljsku dinamiku i sl.), već su prikazane okolnosti koje to iskustvo okružuju. Dobiven je uvid u kontekst unutar kojega se udomitelji bave udomiteljstvom, a ne toliko njihovo konkretno iskustvo bavljenja udomiteljstvom za potrebe konkretnog djeteta. Znanstvena istraživanja te znanstveni i stručni radovi o iskustvima udomiteljstva romske djece ili romskih udomiteljskih obitelji rijetki su, a bili bi značajna pomoć u unapređenju praktičnog djelovanja te podizanja kvalitete udomiteljske skrbi za romsku djecu u skladu s romskom tradicijom i kulturom. Istraživanja o tome bila bi interesantna zbog same specifičnosti romske tradicije i načina na koji oni gledaju institut udomiteljstva te načina na koji se udomitelji regrutiraju. Tako bi bilo korisno 
provesti daljnja istraživanja u populaciji romskih udomitelja na drugim geografskim područjima Republike Hrvatske. Također, bilo bi zanimljivo istražiti postoje li kakve razlike između pružanja udomiteljske skrbi u romskim naseljima i izvan njih pa bi tako sudionici istraživanja mogli biti i romski udomitelji koji ne žive u romskim naseljima, ali i sama djeca, korisnici udomiteljske skrbi. Također, bilo bi zanimljivo provesti longitudinalna istraživanja koja bi u svom fokusu imala životne okolnosti i odgojno-obrazovne ishode romske djece odrasle u romskim udomiteljskim obiteljima te usporediti njihova iskustva s iskustvima romske djece koja su odrasla u udomiteljskim obiteljima iz većinske populacije ili ustanovama i obrnuto. 


\section{Literatura}

Anghel, R., Herczog, M. i Dima, G. (2013). The challenge of reforming child protection in Eastern Europe: The case of Hungary and Romania. Psychosocial Intervention, 22, 239-249.

Braun, V. i Clarke, V. (2006). Using thematic analysis in psyhology. Qualitative Research in Psyhology, 3(2), 77-101.

Brooks, D., James, S. i Barth, R.P. (2002). Preferred characteristics of children in need of adoption: Is there a demand for available foster children. Social service review, 76(4), 575-602.

Casteel, V. (2015). Iskustva srodničkih udomitelja romske nacionalne manjine. Neobjavljen diplomski rad. Zagreb: Pravni fakultet Zagreb, Studijski centar socijalnog rada.

Committee on the Elimination of Racial Discrimination (2015). The Ombudsman for Children in Norway's supplementary report to Norway's combined twenty-firstandtwenty-second periodic report on the International Convention on the Elimination of all forms of Racial Discrimination (CERD). Preuzeto s: http://tbinternet.ohchr.org/Treaties/CERD/Shared\%20 Documents/NOR/INT_CERD_IFN_NOR_20996_E.pdf (20.10.2016.)

D'Arcy, K. i Brodie, I. (2015). Roma Children and Young People in Bulgaria: Patterns of Risk and Effective Protection in Relation to Child Sexual Exploitation. Social Inclusion, 3(4), 1-9.

Daugherty Bailey, J. i Schmidt, V. (2014). Institutionalization of Children in the Czech Republic: A Case of Path Dependency. Journal of Sociology \& Social Welfare, 41(1), 53-75.

DeGarmo, J. (2014). Stalking and Other Dangers Facing Foster Parents. Preuzeto s: http://www.ifapa. org/pdf_docs/WeeklyWordJune242014.pdf (15.10.2016.)

Dobrotić, I. i Laklija, M. (2012). Obrasci društvenosti i percepcija izvora neformalne socijalne podrške u Hrvatskoj. Društvena istraživanja, 115(1), 39-58.

Dugan, I. (2014). Važnost kontakata između udomljene djece i bioloških roditelja. U D. Grujić (ur.), Internacionalna konferencija: Izazovi hraniteljstva na početku 21. veka - iskustva koja kreiraju budućnost (str153-162. ). Beograd: Centar za porodični smeštaj i usvojenje Beograd.

Družić Ljubotina, O., Jelača, N. i Kletečki Radović, M. (2005). Socio-demografska obilježja i iskustva udomiteljskih obitelji. Ljetopis socijalnog rada, 12(1), 89-106.

Elijaš, M. i Laklija, M. (2014). Iskustvo rada socijalnih radnika s romskim obiteljima. Socijalne teme, 1(1), 115-134.

Family, Child, Youth Association (2014). Children in conflict with the law - Report on the outcomes of the qualitative research conducted in Hungary. Preuzeto s: http://www.eurochild.org/ fileadmin/public/06_Projects/Past/Alternatives_to_custody/qualitative_report_hungary. pdf (20.10.2016.)

Forum za kvalitetno udomiteljstvo (2014). 7. Nacionalni susret udomiteljskih obitelji za djecu Sv. Martin na Muri. Preuzeto s: http://www.udomiteljizadjecu.hr/arhiva/prenosimo/7-nacionalni-susret-udomiteljskih-obitelji-za-djecu-sv-martin-na-muri (20.10.2016.)

Heller, S., Smyke, A.T. i Boris, N.B. (2002). Very young foster children and foster families: Clinical challenges and interventions. Infant Mental Health Journal, 23, 555-575.

Kennedy, J., Kukk, K. i Mansens, R. (2010). Children in alternativne care. National surveys. EuroChild Secretariat. Preuzeto s: https://www.eurochild.org/fileadmin/public/05_Library/Thematic_priorities/06_Children_in_Alternative_Care/Eurochild/Eurochild_Publication_-_Children_in_Alternative_Care_-_2nd_Edition_January2010.pdf (20.10.2016.) 
Kletečki Radović, M. i Kregar Orešković, K. (2005). Kvalitativna analiza iskustva udomitelja. Ljetopis socijalnog rada, 12(1), 67-88.

Konvencija o pravima djeteta, Državni zavod za zaštitu materinstva i mladeži, Zagreb, 2001.

Kregar, K. (2004). Socijalna podrška djece smještene u dječjim domovima i udomiteljskim obiteljima u Republici Hrvatskoj. Ljetopis socijalnog rada, 11(2), 229-248.

Laklija, M. (2009). Psihosocijalna obilježja udomitelja i iskustvo udomiteljstva djece. Doktorska disertacija. Zagreb: Pravni fakultet Sveučilišta u Zagrebu, Studijski centar socijalnog rada.

Laklija, M. (2011a). Pristupi udomiteljskoj skrbi za djecu u svijetu i čimbenici koji utječu na ishode udomiteljstva. Revija socijalne politike, 18(3), 291-309.

Laklija, M. (2011b). Doprinos socio-demografskih i psihosocijalnih obilježja udomitelja objašnjenju motiva za bavljenje udomiteljstvom djeteta. Ljetopis socijalnog rada, 19(1), 119-144.

Laklija, M., Blažeka Kokorić, S. i Žabarović, I. (2016). How to improve protection of children's rights to family life? - difficulties in realisation of out of institution care for children with specific risks. Sofia: SGEM, Book 2, Volume I, 679-688.

Laklija, M. i Sladović Franz, B. (2013). Individualni plan skrbi za dijete u udomiteljskoj obitelji. Zagreb: Sirius- Centar za psihološko savjetovanje, edukaciju i istraživanje (priručnik).

MacGregor T. E., Rodger S., Cummings A. L. i Leschied A. W. (2006). The Needs of Foster Parents, A Qualitative Study of Motivation, Support, and Retention. Qualitative Social Work, 5(3), 351-368.

Marčac, T. (2014). Udomiteljstvo romske djece u neromskim obiteljima. Diplomski rad. Zagreb: Pravni fakultet, Studijski centar socijalnog rada.

McFadden, E.J. i McNitt, M. (2008). Children Without Parental Care: The International Foster Care Organization's Response - "Building A Foster Care Community.". Preuzeto s: http:// www.nacsw.org/Publications/Proceedings2008/McFaddenEChildren.pdf (20.10.2016.)

McGaughey, F, Curran, S, Fay, R, Nurse, D i Garland, P. (2012). Roma Communities in Ireland and Child Protection Considerations. Preuzeto s: http://www.PaveePoint.ie/wp-content/ uploads/2013/10/Roma-Communities-in-Ireland-and-Child-Protection-Considerations. pdf (20.10.2016.)

Metcalfe, F. i Humphreys, C. (2002). Fostering Action Research and Action Research in Fostering. Qualitative Social Work, 1(4), 435-450.

Milas, G. (2005). Istraživačke metode u psihologiji i u drugim društvenim znanostima. Jastrebarsko: Naklada Slap.

Ministarstvo zdravstva i socijalne skrbi (2010). Plan deinstitucionalizacije i transformacije domova socijalne skrbi i drugih pravnih osoba koje obavljaju djelatnost socijalne skrbi u Republici Hrvatskoj 2011. - 2016. (2018.). Zagreb: Ministarstvo zdravstva i socijalne skrbi.

Miron, D., Bisaillon, C., Jordan, B., Bryce, G., Gauthier, Y., St-Andre, M. i Minnis, H. (2013). Whose Rights Count? Negotiating Practice, Policy, and Legal Dilemmas Regarding Infant-Parent Contact When Infants are in Out-of-Home Care. Infant mental health journal, 34(2), 177-188.

Mirosavljević, A. (2015). Izvansudska nagodba - perspektiva oštećenika i mladih u sukobu sa zakonom. Doktorska disertacija. Zagreb: Pravni fakultet, Sveučilište u Zagrebu, Studijski centar socijalnog rada. 
Morgan, K. i Baron, R. (2011). Challenging behaviour in looked after young people, feelings of parental self-efficacy and psychological well-being in foster carers. Adoption \& Fostering, 35(1), 18-32.

Nacionalni program za Rome (2003). Zagreb: Vlada Republike Hrvatske.

Nacionalna strategija za prava djece u Republici Hrvatskoj za razdoblje od 2014. do 2020. godine (2014). Zagreb: Vlada Republike Hrvatske, Ministarstvo socijalne politike i mladih.

Nacionalna strategija za uključivanje Roma, za razdoblje od 2013. do 2020. godine (2012). Zagreb: Vlada Republike Hrvatske, Ured za ljudska prava i prava nacionalnih manjina.

Novak, J. (2004). Romska zajednica i međunarodne institucije: tek relativan uspjeh zaštite ljudskih i manjinskih prava. Migracijske i etničke teme, 20(4), 403-432.

O'Higgins, K. (1993). Travelling children in substitute care, Protecting the Culturall Identity of Gypsy, Roma and Traveller Children, Surviving childhood adversity. Belfast: Institute of Irish Studies.

Pećnik, N. i Raboteg-Šarić, Z. (2005). Neformalna i formalna podrška jednoroditeljskim i dvoroditeljskim obiteljima. Revija za socijalnu politiku, 12 (1), 1-21.

Rosenfield, E. (2010). Combating Discimination against the Roma in Europe: Why Current Strategies Aren't Working and What Can Be Done. Topical Research Digest: Minority Rights. Preuzeto s: https://www.du.edu/korbel/hrhw/researchdigest/minority/Roma.pdf(25.10.2018.)

Sanchirico, A. i Jablonka, K. (2000). Keeping Foster Children Connected to Their Biological Parents: The Impact of Foster Parent Training and Support. Child and Adolescent Social Work Journal, 17(3), 185-203.

Sebba, J. (2012). Why do people become foster carers? Oxford: University of Oxford, Rees Centre for Research in Fostering and Education.

Sirius - Centar za psihološko savjetovanje, edukaciju i istraživanje (2017). Analiza sustava skrbi za djecu u zajednici i udomiteljstva za djecu. Analiza potreba za dodatnim osposobljavanjem pomoćnih odgajatelja, odgajatelja i udomitelja, s posebnim naglaskom na transverzalne vještine, završni izvještaj. Preuzeto s: http://centar-sirius.hr/-/1880-2/ (20.10.2018.).

Smith Rotabi, K. i Hübinette, T. (2017). Orphaned and Vulnerable Romany Children and their Protection: Child Adoption, Foster Care, and Child Rights. Preuzeto s: https://ddd.uab.cat/ pub/afin/afinENG/afin_a2017m6n95iENG.pdf (10.10.2018.)

Sweeney, S. i Matthews, Z. (2017). Friends, Families and Travellers: A guide for professionals working with Gypsies, Roma and Travellers in Children's Services. Preuzeto s: https://www. gypsy-traveller.org/wp-content/uploads/2017/03/A-guide-for-professionals-working-with-Gypsies-and-Travellers-in-the-public-care-system.pdf/(10.10.2018.)

Šikić-Mićanović, L., Ivatts, A. R., Vojak, D. i Geiger-Zeman, M. (2015). Socijalno uključivanje djece Roma (RECl+) — Izvještaj za Hrvatsku. Zagreb: Fondacije Otvoreno društvo (OSF), Fond za obrazovanje Roma (REF) i UNICEF.

Škrbina, D. (2010). Podrška udomitelja koji udomljavaju djecu s Down sindromom. Život i škola, 23(1), 9-34.

Šućur, Z. (2004). Utjecaj sociodemografskih čimbenika na poimanje romskog roditeljstva i odrastanja. Društvena istraživanja, 13(4-5), 843-865.

Vandekereckhove, A. (2011). Respect of the rights of children \& young people living in institutional care: state of play. European Network of Ombudspersons for Children. Preuzeto s: 
http://enoc.eu/wp-content/uploads/2015/02/2011-ENOC-report-on-children-in-instit-care.pdf (20.10.2016.)

Vereš, S. (2015a). Velika vrijednost romskih udomiteljskih obitelji u Međimurskoj županiji. Sretno dijete, 9(1), 3.

Vereš, S. (2015b). Specifičnosti udomiteljstva djece romske nacionalnosti iz perspektive CSS-a. Sretno dijete, 9(1), 8-11.

Vijeće Europe (2012). Human rights of Roma and Travellers in Europe. Preuzeto s: https://www.coe. int/t/commissioner/source/prems/prems79611_GBR_CouvHumanRightsOfRoma_WEB. pdf (20.10.2016.)

Whiting, J. B. i Huher P. L. (2007). Significant stress and real rewards: The ecological and ambiguous experiences of foster parents. Relational Child \& Youth Care Practice, 20(2), 9-20.

Vlada Republike Hrvatske (2012). Nacionalna strategïa za uključivanje Roma, za razdoblje od 2013. do 2020. godine. Preuzeto s: http://www.zagreb.hr/UserDocs/mages/arhiva/Nacionalna\%20 strategija\%20za\%20uklju\%C4\%8Divanje\%20Roma\%202013-2020.pdf (23.9.2017.)

Žižak, A. (2008). Udomiteljstvo djece u Hrvatskoj: analiza stanja i prijedlog smjernica. Zagreb: Ured UNICEF-a za Hrvatsku.

Žižak, A., Koller-Trbović, N., Jeđud Borić, I., Maurović, I., Mirosavljević, A. i Ratkajec Gašević, G. (2012). Što nam djeca govore o udomiteljstvu: Istraživanje dječje perspektive udomiteljstva u Hrvatskoj s preporukama za unapređenje. Zagreb: Ured UNICEF-a za Hrvatsku. 


\title{
Foster care from the perspective of Roma foster parents in Roma settlements in Međimurje county
}

\author{
Mateja Krčar \\ Centre for social welfare Čakovec
}

Maja Laklija

University of Zagreb, Faculty of Law, Study centre for social work

\begin{abstract}
Foster care is a form of care for children who can't receive appropriate care in their primary family. It's an alternative to institutional care of children and it's advantage is family environment. The aim of this study was to gain insight into experiences Roma foster parents ( $N=7$ ) with providing foster care in Romani settlements. The results of this study show that the Roma foster parents decided to be foster parent because of their desire to provide appropriate care for children, their conditions for providing foster care and experience with foster care through life. Aggravating factors in providing foster care are reactions of local people, behaviour of the biological parents of children, children's behaviour and life in the Roma settlement due to their specific way of life of Roma. Empowering factors in providing foster care are: social support, so-called emotional "effects" of foster care to the foster parents as well as life in the Roma settlement to preserve the culture, language and identity. The practical implication of the research is to deepen the understanding of this subject area, and the results, except for the consideration of future research, they are providing guidelines for practical action for improving the quality of care for Roma children in foster care and supporting Roma foster parents in according to their tradition and culture.
\end{abstract}

Key words: foster care, children, social care, Roma families, Roma settlements

Međunarodna licenca / International License:

Creative Commons Attribution-NonCommercial-NoDerivatives 4.0. 